\title{
Response of Arachis hypogaea L. to Different Levels of Phosphorus and Boron in Dry Environment
}

\author{
A.A.A. Mekdad \\ Agronomy Department, Faculty of Agriculture, Fayoum University, Fayoum, Egypt. \\ SOILS in arid and semi-arid regions, such Egypt, have low fertility. To improve the soil \\ $\checkmark$ fertility and performance of crops, there is an urgent need to manage agricultural process \\ such as plant nutrition is needed for such environments. To discuss the performance of yield \\ under this conditions, two field trials were conducted using four phosphorus fertilizer levels $\left(\mathrm{P}_{1}\right.$ \\ $30, \mathrm{P}_{2} 45, \mathrm{P}_{3} 60$ and $\mathrm{P}_{4} 75 \mathrm{~kg} \mathrm{P}_{2} \mathrm{O}_{5} /$ fad $)$ and three foliar spray with boron levels $\left(\mathrm{B}_{0}\right.$ tap water, \\ $\mathrm{B}_{1} 100 \mathrm{ppm}$ and $\left.\mathrm{B}_{2} 150 \mathrm{ppm}\right)$ on peanut. Results indicated that yield components, yield and \\ its quality of peanut were positively $(\mathrm{P} \leq 0.01)$ affected by the two factors individually, also \\ had positively $(\mathrm{P} \leq 0.05)$ affected by the various interactions on pod yield. The best pod yield \\ was obtained by the bilateral interaction application of $\mathrm{P}_{4} \times \mathrm{B}_{2}$. Correlation analysis appeared \\ appearance of highly significant with $\mathrm{r}$ values between oil and pod yields.
}

Keywords: Arid regions, Peanut, Oil yield, Correlation analysis.

\section{Introduction}

Peanut (Arachis hypogaea L.) is one of selfpollinating most essential among edible oil seed crops throughout the world. The peanut is an important food and oilseed crop. It is called as the king of oilseeds crops (Hammons, 1982). Peanut ranks the $13^{\text {th }}$ among food crops, $4^{\text {th }}$ among source of the oil seed crops and the $3^{\text {th }}$ among source of vegetable protein crops (Taru et al., 2008).

It is worth to note that, Egypt is suffering from dramatically shortage in edible oils, needed for nutritional consumption. Although in Egypt, the local production from crop oils is about 340 thousand tons in 2015, the Egyptian consumption is about 2.7 million tons in the same season. This indicated that, there is a major gap $(87.4 \%)$ between local production and consumption, which has created importation to fulfill the requirements of market (FAO, 2016).

The yield potential of peanut crop is genetically determined and depends on limiting factors, such as soil and climatic conditions. The fertilization and pests or diseases are among the factors affecting directly the productivity of peanut crop.

Phosphorus is the $2^{\text {th }}$ essential element that increases peanuts production, good quality and enhances water use efficiency. Phosphorus requirement for legumes crops are higher compared with another crops. Due to the essential role of phosphorus element played in the physiological processes for plants, application of phosphorus element to soil deficient in the nutrient leads to increasing peanuts productivity. Phosphorus deficiency is known to reduce flower production, size of pods and adversely affect the formation of root nodules (Panwar et al., 2006). In this respect, Kabir et al. (2013), Kumar (2017) and Zoz et al. (2018) indicated that, increasing the level of phosphorus application increased pod and seed yield and all their attributes of peanut.

Peanut requires the seven micronutrients known to be essential for plants: Boron, chlorine, Copper, Iron, manganese, molybdenum and zincaccording to Murata (2003) in sandy soils of Zimbabwe. Boron element plays major role in the process of physiological of crops, like, regulated metabolism of carbohydrate, contribute in synthesis of protein (B.A.R.C., 2005) and help seed formationin peanut (Naiknware et al., 2015). Boron had essential role in saving flowering and fruit regulation in legumes (Zhang, 2001) and in peanut crop (Singh et al., 2009). Furthermore, it had a positive role on improved the pollination in peanut (Kaisher et al., 2010). This is why the using of boron element in the agricultural practices is increasing slowly. The need for boron element using in peanut is, therefore, to increase the yield.In this respect, recently, boron increase number of branches and pods, pod and seed weight, pods, seeds and oil yield in peanuts. These results were collaborated with Kabir et al. (2013). Naiknware et al. (2015), Quamruzzaman et al.

Corresponding author email: aam07@fayoum.edu.eg

DOI: 10.21608/agro.2017.419.1043

(C)2019 National Information and Documentation Center (NIDOC) 
(2016), Chirwa et al. (2017), Hirpara et al. (2017) and Hirpara et al. (2018).

So, the objective of this investigation is to study the effect of different levels of phosphorus on soil fertilization and foliar spray with boron application on yield and quality of peanut cultivation under dry region conditions (Egypt) over two seasons.

\section{Materials and Methods}

During the two successive summer seasons 2017 and 2018, two field experiments were conducted on the Experimental Farm, Faculty of Agriculture, Fayoum University, Egypt. The experimental soil (Southeast Fayoum; 29¹7’N, 3053'E) was sandy loam with organic matter of $0.74 \%$, electrical conductivity of $4.36 \mathrm{dS} / \mathrm{m}$ and $\mathrm{pH}$ of 7.24 , to study the effect of phosphorus soil fertilizer levels and foliar spray with boron levels application on yield and its components and quality of peanuts (Arachis hypogaea L.). The experimental unit area was $10.5 \mathrm{~m}^{2}$ consisting of five ridges, $3.5 \mathrm{~m}$ long and $60 \mathrm{~cm}$ apart. Peanut seeds were sown on April $8^{\text {th }}$ and $15^{\text {th }}$ in the first and second seasons, respectively. Peanut variety Giza $6 c v$. was inoculated just before sowing with the specific rhizobium bacteria inoculants. The recommended agricultural practices for growing peanut were followed except the factors under study which arranged in split-plot in RCBD design with three replicates. Phosphorus soil fertilizer levels, as Calcium superphosphate $\left(15.5 \% \mathrm{P}_{2} \mathrm{O}_{5}\right)$ was added during the seed bed preparation at four levels of 30 $\left(\mathrm{P}_{1}\right), 45\left(\mathrm{P}_{2}\right), 60\left(\mathrm{P}_{3}\right)$ and $75\left(\mathrm{P}_{4}\right) \mathrm{kg} \mathrm{P}_{2} \mathrm{O}_{5} \backslash$ fad were arranged in the main treatments. While, three foliar spray with boron levels in the form of boric acid, i.e., $0\left(\mathrm{~B}_{0}\right), 100\left(\mathrm{~B}_{1}\right)$, and $150\left(\mathrm{~B}_{2}\right)$ ppm were applied as foliar spray in two sprays at vegetative stage (30 and 50 days after sowing) and randomly distributed in sub treatments. Boric acid (Sigma-Aldrich Company, Germany) were applied, by $0.1 \%(\mathrm{v} / \mathrm{v})$ Tween-20 as surfactant. The foliar solutions volume was $200 \mathrm{~L} /$ fad conducted by hand sprayer. Nitrogen was added as ammonium sulfate $(20.6 \% \mathrm{~N})$ at $30 \mathrm{~kg}$ $\mathrm{N}$ fad $^{-1}$ rate in three equal doses at 15, 30 and 45 days after sowing. Potassium fertilizer as potassium sulfate, $48 \% \mathrm{~K}_{2} \mathrm{O}$ at $24 \mathrm{~kg} \mathrm{k}_{2} \mathrm{O}$ fad ${ }^{-1}$ rate and organic fertilizer at $20 \mathrm{~m}^{3} \mathrm{fad}^{-1}$ rate were incorporated into the soil surface during seed bed preparation. Surface irrigation was adopted as recommended. The preceding winter crops were faba bean and sugar beet in the first and the second seasons, respectively.

Peanut was manually harvested on September $9^{\text {th }}$ and $11^{\text {th }}$ in the first and second seasons, respectively. At harvest, a random sample of ten plants were taken from each sub plot to determine number of branches plant $^{-1}$, number of pods plant ${ }^{-1}$, weight of pods plant ${ }^{-1}$, number of seeds plant ${ }^{-1}$ and weight of seeds plant $t^{-1}$. Plants on the middle two rows in each sub plot were harvested and dried to calculate, pods and seed yield fad ${ }^{-1}$. Samples, each of $50 \mathrm{~g}$ seeds, were grinded into fine powder and stored in brown glass bottles for chemical analysis. Seed oil and $\mathrm{N} \%$, were determined according to the methods described by A.O.A.C. (1990), and the seed protein $\%$ was calculated by multiplying total nitrogen $\%$ by 6.25 . Seed oil and protein yields per faddan were calculated by multiplying seed oil and N\% by seed yield fad $^{-1}$.

All obtained data were statistically analyzed according to the technique of analysis of variance (ANOVA) for the spilt- plot design as outlined by Gomez \& Gomez (1984), using MSTAT- C (Michogen, USA). Least Significant Difference (LSD, at $5 \%$ and $1 \%$ levels of probability) was used to test the differences between treatments means.

\section{$\underline{\text { Results and Discussion }}$}

Effect of phosphorus soil fertilization levels application

Data in Tables 1, 2 and 3 illustrated that increasing phosphorus soil levels fertilizer from 30 to $75 \mathrm{~kg} \mathrm{P}$ fad $^{-1}$ highly significantly increased $(\mathrm{P} \leq 0.01)$ on all traits of peanut crop over two seasons. The maximum superior treatments were the phosphorus at $75 \mathrm{~kg} \mathrm{P}_{2} \mathrm{O}_{5}$ fad $^{-1}$. Increasing phosphorus level to $75 \mathrm{~kg} \mathrm{P}_{2} \mathrm{O}_{5}$ fad $^{-1}$ resulted in gradual increase in growth traits such as, number of branches plant $^{-1}$, number of pods plant ${ }^{-1}$, weight of pods plant ${ }^{-1}(\mathrm{~g})$, number of seeds plant ${ }^{-1}$ and weight of seeds plant ${ }^{-1}(\mathrm{~g})$ amounted to (45.74 and $47.63 \%$ ), (43.92 and 46.43\%), (53.20 and 52.51\%), (43.61 and $43.05 \%)$ and (57.23 and 58.01\%), respectively. Concerning, phosphorus at the highest level $75 \mathrm{~kg}$ $\mathrm{P}_{2} \mathrm{O}_{5}$ fad $^{-1}$ effect exhibited similar trends in yield and quality traits such as, seed yield (ton $\mathrm{fad}^{-1}$ ), pod yield (ton fad $\left.{ }^{-1}\right)$, oil yield $\left(\mathrm{kg} \mathrm{fad}^{-1}\right)$ and protein yield $(\mathrm{kg}$ $\mathrm{fad}^{-1}$ ) amounted to (89.36 and 95.45\%), (28.13 and $31.67 \%)$, (102.89 and 109.64\%) and (117.70 and $121.00 \%$ ), respectively. Furthermore phosphorus at the same level $75 \mathrm{~kg} \mathrm{P}_{2} \mathrm{O}_{5}$ fad $^{-1}$ in quality traits, such as seed oil $\%$, nitrogen $\%$ and protein $\%$ amounted to $(6.78$ and $7.28 \%),(14.78$ and $12.82 \%)$ and (14.59 and $13.05 \%)$, respectively, comparing with $30 \mathrm{~kg}$ $\mathrm{P}_{2} \mathrm{O}_{5}$ fad $^{-1}$ level. The raise in peanut productivity 
due to phosphoric fertilization may be refer to the activation of processes of metabolic, where its function in building nucleic acid and phospholipids (Marschner, 1986). Increases in the previous traits with increasing phosphorus levels may be due to that phosphoric fertilization is known to help improving a wider root system and thus helping plants to extract nutrient elements and water from different depth. This, in turn, could improve the performance of plants which were reflected in crop production. Many investigators confirmed such respond to phosphorus. Kabir et al. (2013) and recently, Kumar (2017) and Zoz et al. (2018) indicated that, increasing the level of phosphoric fertilization leads to an increased number of pods and seeds, weight of pods and seeds and yield in terms of pod, seed and oil of peanut.

\section{Effect of foliar spraying with boron concentrations}

The data on peanut yield and yield component traits viz., number of branches plant ${ }^{-1}$, number and weight of pods plant ${ }^{-1}$, number and weight of seeds plant $^{-1}$, as well as yield in terms of pod, seed, oil and protein $\mathrm{fad}^{-1}$, furthermore, quality traits such as seed oil, nitrogen and seed protein $\%$ as influenced by foliar spray with boron application were presented in Tables 1, 2 and 3 over two seasons. Increasing foliar spray with boron application up to $\mathrm{B}_{2}$ $(150 \mathrm{ppm})$ had significant $(\mathrm{P} \leq 0.01)$ positive effects on peanut yield, yield components and quality traits. The $\mathrm{B}_{2}$ (150ppm) significantly exceeded the $\mathrm{B}_{0}$ (control, tap water) in all formers traits. In the same order of previous traits foliar spraying with boron at $150\left(\mathrm{~B}_{2}\right)$ ppm increased yield components traits viz., number of branches plant ${ }^{-1}$, number and weight of pods plant ${ }^{1}$, number and weight of seeds plant $^{-1}$ by $5.85 \& 8.22,7.01 \& 7.24,5.18 \& 5.09$, $7.03 \& 7.27$ and $9.65 \& 9.22 \%$, respectively, while yield traits viz., pod, seed, oil and protein $\mathrm{fad}^{-1}$ by $11.45 \& 9.70,17.19 \& 17.74,18.58 \& 19.49$ and $20.17 \& 21.01$, also increased quality traits such as seed oil, nitrogen and seed protein $\%$ by 1.49 \& $1.55,3.01 \& 2.71$ and $2.88 \& 2.91 \%$, in the $1^{\text {st }}$ and $2^{\text {nd }}$ season, respectively compared with $\mathrm{B}_{0}$ (control treatment). The positive effect of increasing foliar spray of boron application on number of pods and seed of peanut may be due to its role in cell elongation and saving flowering and fruit regulation (Zhang, 2001 and Singh et al., 2009), furthermore it had a positive role on improved the pollination (Kaisher et al., 2010). Boron increase number of branches and pods, pods and seed weight, pod, seed and oil yield in peanuts, similar findings also were recorded by Helmy \& Shaban (2008), Kabir et al.
(2013), Helmy \& Ramadan (2014), Naiknware et al. (2015), Quamruzzaman et al. (2016), Chirwa et al. (2017), Hirpara et al. (2017) and Quamruzzaman et al. (2018). Furthermore, concerning the positive effect of boron application onsugar beet (Mekdad, 2015 a and Mekdad \& EL-Sherif, 2016) and Mekdad \& Rady (2016) reported that increasing foliar spray with boron increased significantly the productivity of sugar beet, while Mekdad (2015 b) illustrated that increasing foliar spraying with micronutrients mixture levels ( $\mathrm{Fe}, \mathrm{Mn}, \mathrm{Zn}, \mathrm{Cu}, \mathrm{B}$ and $\mathrm{Mo}$ ) increased significantly the productivity of sesame crop. The assessed $\mathrm{Zn}$ foliar application rates, up to $1.00 \mathrm{~g} \mathrm{~L}^{-1}$ resulted in gradual increased most measured characteristics namely, seed, straw and pod yields, number of pods plant ${ }^{-1}$, weight of pods plant ${ }^{-1}$, number of seeds plant ${ }^{-1}$, weight of seeds plant $^{-1}$, weight of 100 pods and weight of 100 seed, seed oil yield, $\mathrm{N} \%$, protein $\%$, and protein yield of groundnut in $1^{\text {st }}$ and $2^{\text {nd }}$ seasons (Mekdad, 2017).

\section{Interactions effect between phosphorus and boron levels}

Data in Table 4 illustrated that number of pods plant ${ }^{-1}(31.37)$ and pods yield ton fad $^{-1}(1.71)$ in the first season, while quality traits in terms of seed oil $(49.80 \%)$, nitrogen $(4.06 \%)$ and protein $(25.38 \%)$ in the second one were significantly $(\mathrm{P} \leq 0.05)$ affected by the interaction application of soil phosphorus and foliar spray with boron levels. Application of $\mathrm{P}_{4}$ $\left(75 \mathrm{~kg} \mathrm{P}_{2} \mathrm{O}_{5}\right.$ fad $\left.^{-1}\right)$ with $\mathrm{B}_{2}$ level $(150 \mathrm{ppm})$ increased significantly the previous of studied traits. Chirwa et al. (2017), reported that the interaction between soil phosphorus and foliar spray with boron levels application increased significantly pod yield.

\section{Yield analysis study \\ Correlation coefficient}

The correlation coefficients showed in Table 5 between oil yield ton $\mathrm{fad}^{-1}$ and each of number of branches, pod and seed plant ${ }^{-1}$ as well as weight of pod and seed plant ${ }^{-1} \mathrm{~g}$, furthermore pod and seed yield ton $\mathrm{fad}^{-1}$ and oil \% were computed, in order to shed light on the relationship of effectual traits interest. Positive effect and significantly $(\mathrm{P} \leq 0.01)$ correlations were acquired between oil yield ton $\mathrm{fad}^{-1}$ and each of seed yield ton $\mathrm{fad}^{-1} \mathrm{r}=0.998^{* *}$ over two season, as well as number of pod plant ${ }^{-1} \mathrm{r}=$ $0.945^{* *}$ and $0.937^{* *}$ in both seasons, respectively. The results obtained in Table 6 showed that there are three traits, i.e. seed yield, oil (\%) and number of pod in 2017 season and two traits, i.e. seed yield and oil (\%) in 2018 season were a highly significant contributed to variation in oil yield. 


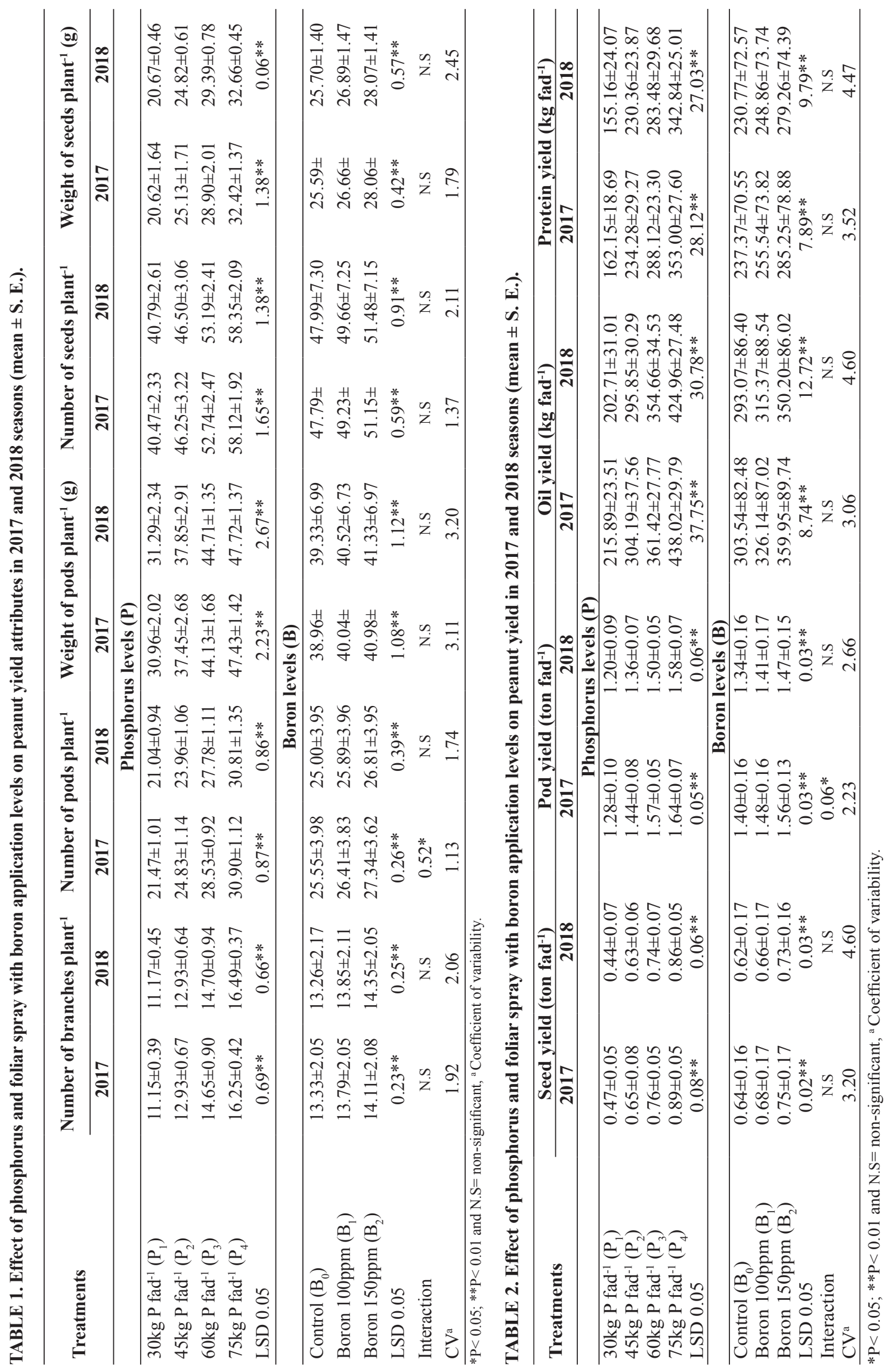

Egypt. J. Agron. 41, No.1 (2019) 

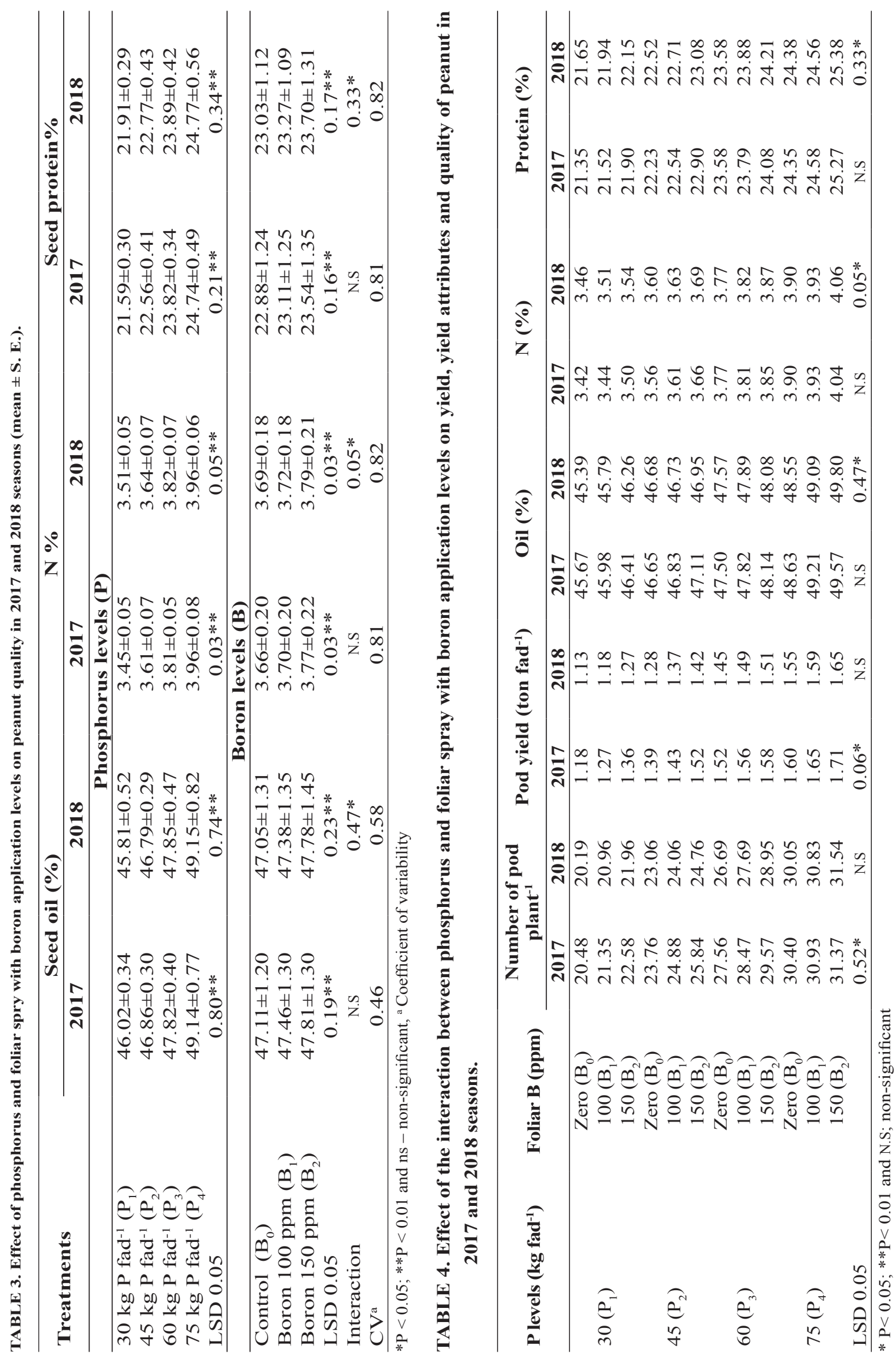

Egypt. J. Agron. 41, No.1(2019) 


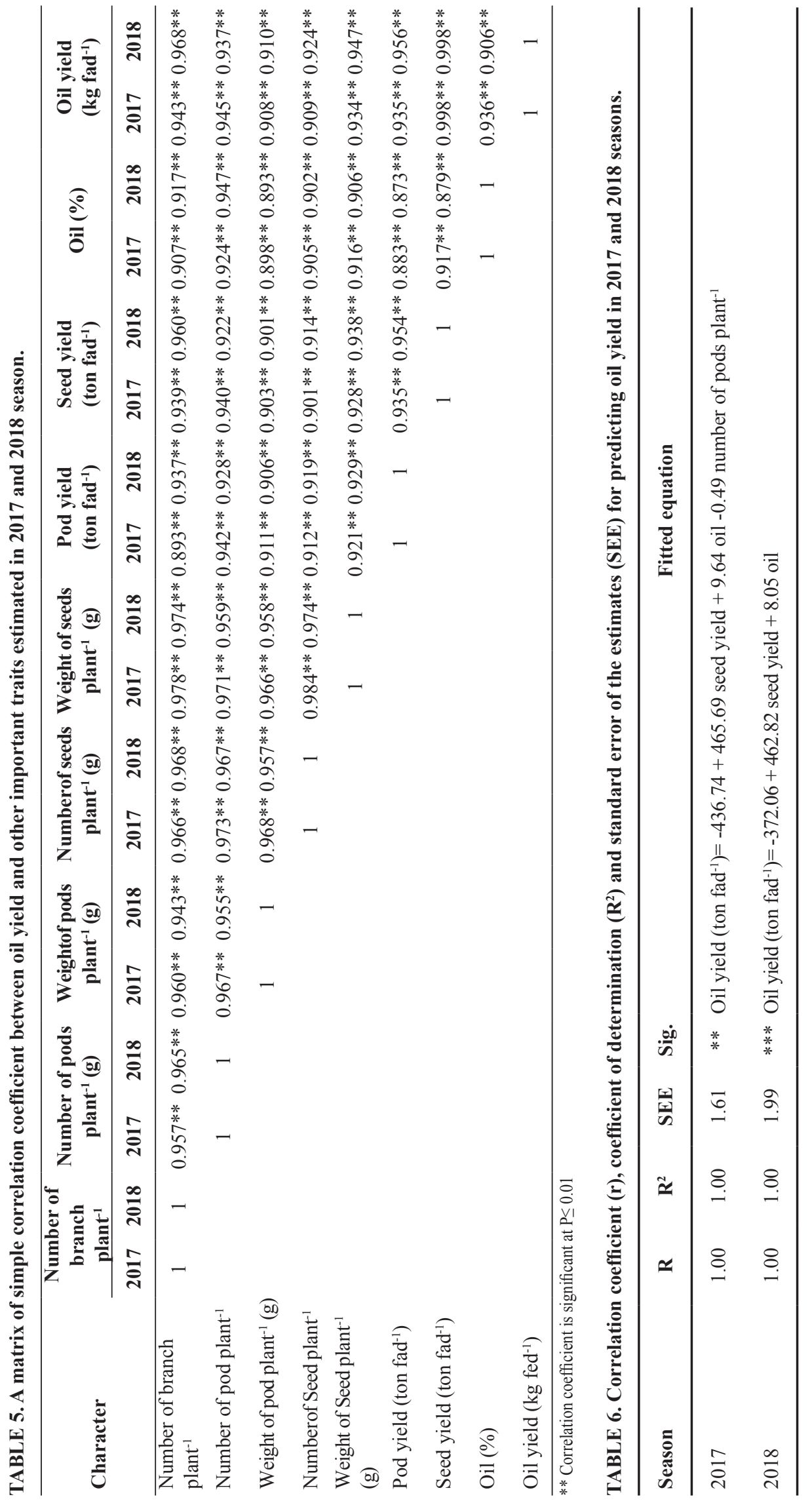

Egypt. J. Agron. 41, No.1 (2019) 


\section{References}

A.O.A.C. (1990) "Official Methods of Analysis". Association of Official Analytical ChemistsInternational. $15^{\text {th }}$ ed. AOAC-Int., Arlington, VA.

B.A.R.C. (2005) Bangladesh Agricultural Research Council. Fertilizer recommendation guide- Farmgate, New Airport Road, Dhaka-1215; 2005.

Chirwa, M., Mrema, J.P., Mtakwa, P.W., Kaaya, A. and Lungu, O.I. (2017) Yield response of groundnut (Arachis hypogaea L.) to boron, calcium, nitrogen, phosphorus and potassium fertilizer application. International Journal of Soil Science, 12(1), 18-24.

FAO (Food and Agriculture Organization of the United Nations), (2016) FAOSTAT: World Crop Production data.

Gomez, K.A and Gomez, A.A. (1984) "Statistical Procedures for Agriculture Research". $2^{\text {nd }}$ ed. John Wiley and Sons. New York, USA. 680pp.

Hammons, R.O. (1982) Origin and early history of the pea nut. In: "Peanut Science and Technology", H.E. Pattee and C.T. Young (Ed.), pp.1-20.

Helmy, A.M. and Ramadan, M.F. (2014) Yield quality parameters and chemical composition of peanut as affected by potassium and gypsum applications under foliar spraying with boron.Communications in Soil Science and Plant Analysis, 45, 2397-2412.

Helmy, A.M. and Shaban, Kh.A. (2008) Response of peanutsto $\mathrm{K}$ fertilization and foliar spraying with zinc and boron under sandy soil conditions. Zagazig J. Agric. Res. 35(2), 343-362.

Hirpara, D.V., Sakarvadia, H.L., Savaliya, C.M., Ranpariya, V.S. and Modhavadiya, V.L. (2017) Effect of different levels of boron and molybdenum on growth and yield of summer groundnut (Arachis hypogaea L.) under medium black calcareous soils of south Saurashtra region of Gujarat. International Journal of Chemical Studies, 5(5), 1290-1293.

Kabir, R., Sabina Yeasmin, Islam, A.K.M.M. and Sarkar, M.R. (2013) Effect of phosphorus, calcium and boron on the growth and yield of groundnut (Arachis hypogea L.). International Journal of Bio-Science and Bio-Technology, 5(3), 51-59.

Kaisher, A.M., Rahman, M.A., Amin, A.H.A.,
Amanullah, A.S.M. and Absanullah, A.S.M. (2010) Effect of sulphur and boron on the seed yield and protein content of mungbean. Bangladesh Res. Publications Journal, 3(4), 1181-6.

Kumar, N., Pallavi, A.H.N. and Naveen, N.E. (2017) Economizing phosphorus use in groundnut production by exploiting phosphorus build -up in soil. International Journal of Current Microbiology and Applied Sciences, 6(10), 251-255.

Marschner, H. (1986) "Mineral Nutrition of Higher Plants". Inst. of Plant Nutrition, Univ. of Hoheheim, F.R.G. Academic. Press, Harcout, Brace. Jovanvich Publisher. London.

Mekdad, A.A.A. (2015 a) Sugar beet productivity as affected by nitrogen fertilizer and foliar spraying with boron. International Journal of Current Microbiology and Applied Sciences, 4(4), 181-196.

Mekdad, A.A.A. (2015 b) Effects of planting dates, foliar microelement mixture rates and weeding regimes on performance of sesame crop (Sesamum indicum L.). Journal Plant Production, Mansoura Univ. 6(12), 2103-2121.

Mekdad, A.A.A. (2017) Response of peanut to nitrogen fertilizer levels and foliar zinc spraying rates in newly reclaimed sandy soils. Journal of Plant Production, Mansoura Univ. 8(2), 153 -159.

Mekdad, A.A.A and El-Sherif, A.M.A. (2016) Performance of two sugar beet varieties under fertilization with potassium and foliar spraying with micronutrients. Egypt Journal of Agronomy, 38(2), 189-207.

Mekdad, A.A.A. and Rady, M.M. (2016) Response of Beta vulgaris L. to nitrogen and micronutrients in dry environment. Plant Soil Environ. 62(1), 23-29.

Murata, M.R. (2003) The impact of soil acidity amelioration on groundnut production on sandy soils of Zimbabwe. Ph.D. Thesis, Fac. Natural and Agric. Pretoria Pretoria Uni.

Naiknware, M.D., Pawar, G.R. and Murumkar, S.B. (2015) Effect of varying levels of boron and sulphur on growth, yield and quality of summer groundnut (Arachis hypogea L.). International Journal Tropic Agriculture, 33(2), 471-474.

Panwar, A.S., Singh, N.P., Saxena, D.C. and Hazarika, 
U.K. (2006) Yield and quality of groundnut seed as influence by phosphorus, biofertilizer and organic manures. Indian Journal of Hill Farming, (CAB Abstracts).

Quamruzzaman, M., Ullah, M.J., Karim, M.F., Islam, N., Rahman, M.J. and Sarkar, M.D. (2016) Response of boron and light on morph- physiology and pod yield of two peanut varieties. International Journal of Agronomy, 9, 1-9.

Quamruzzaman, M., Ullah, M.J., Karim, M.F., Islam, N., Rahman, M.J. and Sarkar, M.D. (2018) Reproductive development of two groundnut cultivars as influenced by boron and light. Information Processing in Agricultural, 5, 289-293.

Singh, A.L., Jat, R.S. and Misra, J.B. (2009) Boron fertilization is a must to enhance peanut production in
India. In: The Proceedings of the International Plant Nutrition Colloquium XVI.

Taru, V.B., Khagya, I.Z., Mshelia, S.I. and Adebayo, E.F. (2008) Economic efficiency of resource use in groundnut production in Adamawa State of Nigeria. World Journal of Agricultural Science, 4(5), 896-900.

Zhang, L. (2001) Effect of foliar application of boron and dimilin on soybean yield. Mississippi. Agricu. Exp. Stat., Res. Rep. 22, 1-5.

Zoz, T., Fiorese, D.A., Pivetta, L.A., Zoz, A., Zoz, J. and Zuffo, A.M. (2018) Phosphorus and potassium fertilization in creeping peanut. Revista Scientia Agraria, 19(1), 153-159.

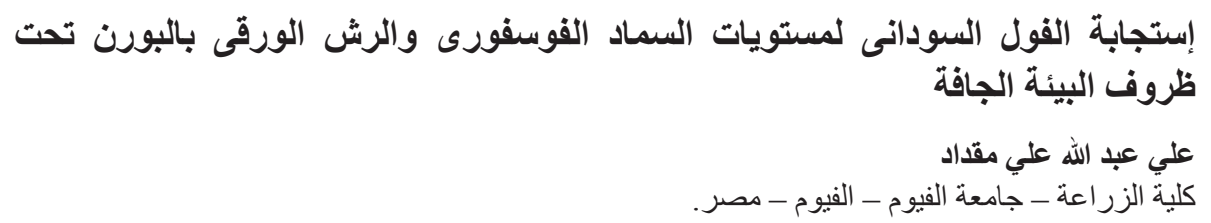

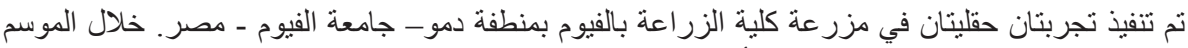

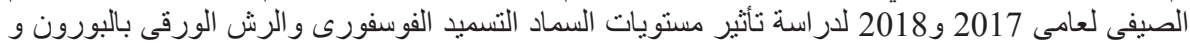

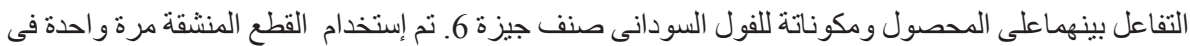

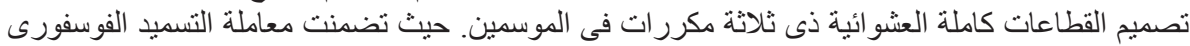

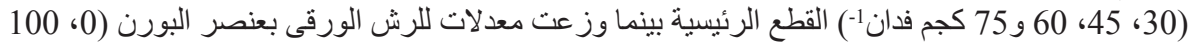

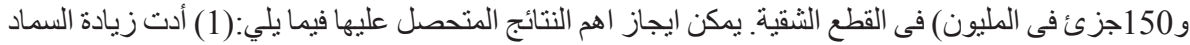

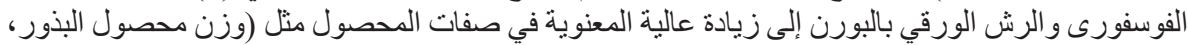

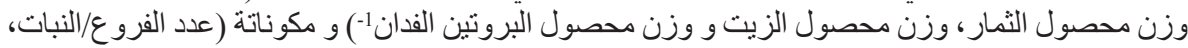

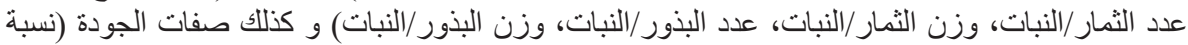

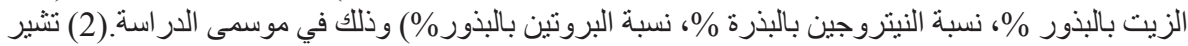

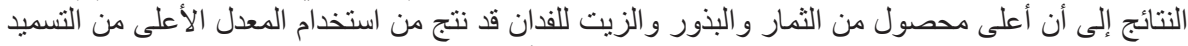

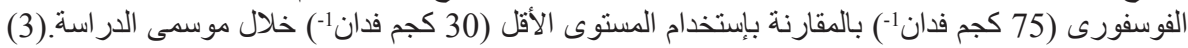

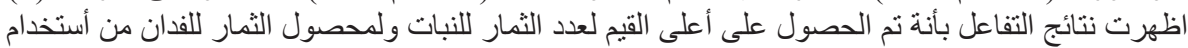

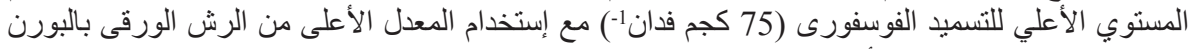

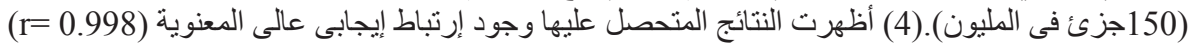
بين محصول الزيت و محصول) البذور في كلا الموسمين. 